\title{
Herbicide-Resistant Weed Seeds Contaminate Grain Sown in the Western Australian Grainbelt
}

\author{
Pippa J. Michael, Mechelle J. Owen, and Stephen B. Powles*
}

\begin{abstract}
Preventing the introduction of weeds into the farming system through sowing of clean seeds is an essential component of weed management. The weed seed contamination of cleaned grain and herbicide resistance levels of the recovered weed seeds were examined in a study conducted across 74 farms in the Western Australian grainbelt. Most farmers grew and conserved their own crop seed. The majority of cleaned samples had some level of seed contamination from 11 foreign weed and volunteer crop species, with an average of 62 seeds $10 \mathrm{~kg}^{-1}$ grain, substantially higher than the 28 seeds $10 \mathrm{~kg}-1$ grain expected by farmers. The most common weed contaminants across all samples were rigid ryegrass, wild radish, brome, and wild oat. When categorized by crop type, rigid ryegrass was the most frequent contaminant of cereal crops (barley and wheat), however wild radish was the most frequent contaminant of lupin crops. Uncleaned crop seed samples had almost 25 times more contamination than cleaned crop seed. Herbicide resistance was highly prevalent within rigid ryegrass populations recovered from cleaned grain except for glyphosate, which controlled all populations tested. Some resistance was also found in wild radish and wild oat populations; however, brome was susceptible to fluazifop. This study has shown that farmers are unknowingly introducing weed seeds into their farming systems during crop seeding, many of which have herbicide resistance.

Nomenclature: Fluazifop; glyphosate; brome, Bromus spp.; rigid ryegrass, Lolium rigidum Gaudin; wild oat, Avena fatua L.; wild radish, Raphanus raphanistrum L.; barley, Hordeum vulgare L.; lupin, Lupinus spp.; wheat, Triticum aestivum L. Key words: Survey, grain cleaning, weed seed dispersal.
\end{abstract}

In world cropping, infesting weeds are the major biotic factor causing crop losses. As most crop weeds are annual species, seed production enables them to persist from year to year. Dispersal and spread of seeds is an important biological factor affecting weed control and an essential element when considering crop weed management strategies (Thill and Mallory-Smith 1997). Many weed species rely on the action of humans for their spread as they have no particular specialization for biotic or abiotic seed dispersal (Benvenuti 2007).

Many invasive plants have been introduced accidentally or intentionally through global commerce (Mack et al. 2000), with exotic weeds in agricultural systems being typical cases of unintended introduction (Shimono and Konuma 2008). Within agro-ecosystems, humans influence long-distance seed dispersal of weed species through the movement of machinery, especially during harvesting and tillage operations and manure spreading, and by the accidental inclusion of weed seeds in harvested crop seeds (Barroso et al. 2006; Blanco-Moreno et al. 2004; Llewellyn and Allen 2006; McCanny and Cavers 1988; Pleasant and Schlather 1994; Thill and Mallory-Smith 1997). Several weed species have adapted to imitate crop seed characteristics and are easily overlooked or hard to remove during seed cleaning operations, thus they are re-introduced into crop fields during the subsequent crop seeding process (Benvenuti 2007).

Previous studies have identified high levels of weed seed contamination in crop seed in Australia (Moerkerk 2002; Niknam et al. 2002; Powles and Cawthray 1999) and internationally (Dewey et al. 1985; Dewey and Whitesides 1990; Shimizu 1998; Shimono and Konuma 2008). Preventing the introduction of weed seed into crop fields through the planting of weed-free crop seeds is an essential component of good weed management and has been shown to prevent the

\footnotetext{
DOI: 10.1614 /WS-D-09-00082.1

* First author: Research Fellow, Department of Environment and Agriculture, Curtin University, Northam, WA 6401, Australia; second and third authors: Senior Research Officer and Professor, Western Australian Herbicide Resistance Initiative, University of Western Australia, 35 Stirling Highway, Crawley, WA 6009, Australia. Corresponding author’s E-mail: p.michael@curtin.edu.au
}

spread of several weed species (e.g., corn cockle, Agrostemma githago L.) (Harper 1977). As well as adding to the weed seedbank already present in the field, foreign seed contamination of crop seed may also introduce new unwanted species and herbicide-resistant biotypes into farming systems with potentially devastating consequences. It has long been suspected that many infestations of herbicide-resistant weed populations are a direct result of seeding with contaminated crop seed (Thill and Mallory-Smith 1997). With herbicideresistant rigid ryegrass, wild oat, and wild radish populations occurring at high frequencies in Western Australian cropping regions (Owen et al. 2007; Owen and Powles 2009; Walsh et al. 2007), it is likely that herbicide-resistant weed seeds are being further dispersed by human-mediated processes including contamination of crop seed. Owen et al. (2007) found that rigid ryegrass was present in more than $90 \%$ of cropping fields surveyed with most populations resistant to the acetyl CoA carboxylase (ACCase)-inhibiting herbicide diclofopmethyl. Wild oat and wild radish were found in less than half of these cropping fields ( 43 and $27 \%$, respectively); however, $70 \%$ of wild oat populations contained some level of resistance to diclofop-methyl, and $54 \%$ of wild radish populations exhibited resistance to the acetolactate synthase (ALS)-inhibiting herbicide chlorsulfuron (Owen and Powles 2009; Walsh et al. 2007).

The aim of this study was to determine the extent of weed seed contamination present in crop seed used in Western Australian grainbelt farming systems, as well as to understand the effect of seed source and seed cleaning techniques on the level of contamination. Furthermore, we sought to identify herbicide resistance levels in the infesting weed seeds.

\section{Materials and Methods}

Grain Collection. During May 2007 and 2008, prior to crop seeding, 154 crop seed samples were collected from storage bins on 74 farms across four major regions of the Western Australian grainbelt (Figure 1; Table 1). Farmers provided 


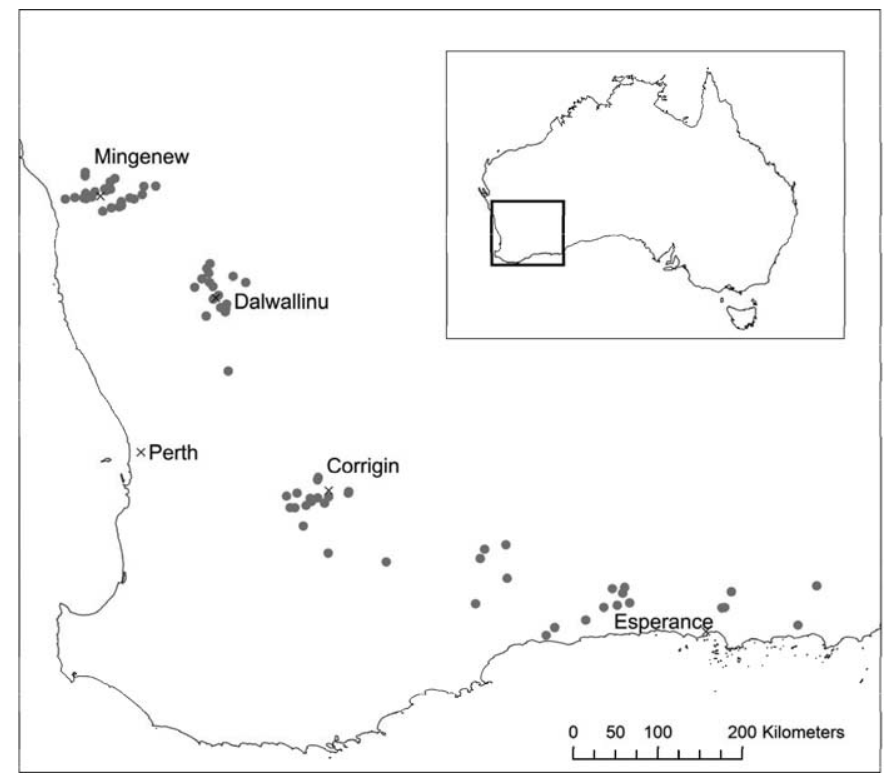

Figure 1. Map of the grainbelt of Western Australia indicating the 74 locations where crop seeds were collected in May 2007 and 2008. A total of 154 samples were taken from four regions: Mingenew (50), Dalwallinu (35), Corrigin (31), and Esperance (38).

cleaned crop seed samples of wheat and samples of either barley or lupin crops. Each farmer was also surveyed to determine individual grain cleaning management practices and perception of the level of weed seed contamination. Crop seed cleaning methods were categorized as follows: combination, gravity table, rotary screen, and sieves. Combination techniques used a variety of cleaning methods.

An average of $10 \mathrm{~kg}$ of grain was collected per sample. A further 16 crop seed samples that were not cleaned by the farmer were used in the study as a comparison of weed contamination of cleaned versus uncleaned grain. Each crop seed sample was analyzed for weed seed content using a seed clipper, ${ }^{1}$ which screened and aspirated the grain over a series of sieves $(2.8,2.0$, and $1.0 \mathrm{~mm})$. Crop seed samples were also hand-cleaned when necessary. This enabled seeds to be separated based on differences in width, thickness, and weight. Weed seeds were quantified and identified into species.

Herbicide Resistance Testing of Contaminating Crop Seed. During the 2008 growing season (May to September), seeds from the four most common weed species recovered from grain samples (rigid ryegrass, wild radish, brome, and wild oat) were each germinated in $500-\mathrm{ml}$ plastic containers containing $1 \%(\mathrm{w} / \mathrm{v})$ solidified agar-water. Weed seeds were germinated in a controlled growth cabinet with alternating 25/15 C, 12-h light/dark for a period of $5 \mathrm{~d}$. Approximately 40 seedlings for each sample were then transplanted into plastic trays (30 by 40 by $10 \mathrm{~cm}$ ) containing potting mix (50\% composted pine bark, $25 \%$ peat, and $25 \%$ river sand) for each herbicide application. Trays were kept outdoors at the University of Western Australia in Perth $\left(31^{\circ} 59^{\prime} 4.19^{\prime \prime} \mathrm{S}\right.$, $115^{\circ} 49^{\prime} 8.68^{\prime \prime} \mathrm{E}$ ) and watered and fertilized as required. For almost all populations, seedling survival was high, ensuring that approximately 40 individual seedlings in each sample were treated with each herbicide.

When seedlings reached the two-leaf stage, they were treated with herbicide together with wetting agent as required
Table 1. Number of grain samples collected from 74 locations within the grainbelt of Western Australia.

\begin{tabular}{lccc}
\hline & \multicolumn{2}{c}{ Cleaning method } & \\
\cline { 2 - 3 } Crop & External & Self & Total \\
\hline Barley & 27 & 14 & 41 \\
Wheat & 65 & 20 & 85 \\
Lupins & 17 & 11 & 28 \\
Total & 109 & 45 & 154 \\
\hline
\end{tabular}

(Table 2) (upper recommended field rates) using a custombuilt, dual nozzle cabinet sprayer ${ }^{2}$ delivering herbicide in $110 \mathrm{~L} \mathrm{ha}^{-1}$ water at $200 \mathrm{kPa}$, at a speed of $3.6 \mathrm{~km} \mathrm{~h}^{-1}$. A range of herbicides commonly used to control each weed species were chosen and applied at the recommended commercial field rate for Australia (Table 2). When rigid ryegrass and wild oat seedlings were at the two-leaf stage, the ACCase-inhibiting herbicide diclofop-methyl was applied. Rigid ryegrass seedlings that survived diclofop-methyl at $21 \mathrm{~d}$ after treatment were cut back to a height of $2 \mathrm{~cm}$, and any regrowth was treated $1 \mathrm{wk}$ later with the ACCase-inhibiting herbicide sethoxydim. Approximately 40 seedlings were also each treated with the herbicides clethodim, sulfometuron-methyl, and glyphosate at the two- to three-leaf stage. When brome seedlings were at the two-leaf stage, a minimum of 40 seedlings from each sample were treated with the ACCase-inhibiting herbicide fluazifop. When wild radish seedlings were at the two-leaf stage, approximately 40 seedlings from each sample were treated with the ALS-inhibiting herbicide chlorsulfuron.

Known susceptible and resistant controls were used for each species and for each herbicide treatment in all experiments, with $100 \%$ control of the known susceptible and high survival $(>90 \%)$ of the known resistant populations (data not shown). The effect of the herbicide was assessed by determining seedling mortality $21 \mathrm{~d}$ after herbicide treatment. Seedlings were assessed as dead if they had no new growth or active tiller formation (live plants had strongly tillered) and plant survival was converted to a percentage. Populations were classed as resistant if more than $1 \%$ of seedlings survived the treatment, and susceptible if all plants died. Some populations were not screened with all herbicides due to a small sample size (less than 10 germinating seeds) for these populations, nor were all herbicide treatments replicated.

Statistical Analysis. In addition to analysis of all foreign seed contaminants (which included both weed and volunteer crop

Table 2. Herbicides and adjuvants applied to two- to three-leaf rigid ryegrass, brome, wild oat, and wild radish populations (as indicated by X) during the 2008 growing season. See Sources of Materials for information on numbered notations.

\begin{tabular}{|c|c|c|c|c|c|c|}
\hline \multirow[b]{2}{*}{ Chemical class } & \multirow[b]{2}{*}{$\begin{array}{l}\text { Active } \\
\text { ingredient }\end{array}$} & \multirow[b]{2}{*}{$\begin{array}{c}\text { Rate } \\
\left(\mathrm{g} \text { ai ha }{ }^{-1}\right)\end{array}$} & \multicolumn{4}{|c|}{ Weed species } \\
\hline & & & $\begin{array}{l}\text { Rigid } \\
\text { ryegrass }\end{array}$ & Brome & $\begin{array}{l}\text { Wild } \\
\text { oat }\end{array}$ & $\begin{array}{l}\text { Wild } \\
\text { radish }\end{array}$ \\
\hline \multirow{2}{*}{$\begin{array}{l}\text { Aryloxyphenoxy- } \\
\text { propionate }\end{array}$} & Diclofop $^{4 a}$ & 563 & $\mathrm{X}$ & & $\mathrm{X}$ & \\
\hline & Fluazifop $^{5 a}$ & 779 & & $\mathrm{X}$ & & \\
\hline \multirow[t]{2}{*}{ Cyclohexanedione } & Clethodim $^{6 \mathrm{~b}}$ & 60 & $\mathrm{X}$ & & & \\
\hline & Sethoxydim ${ }^{4 a}$ & 186 & $\mathrm{X}$ & & & \\
\hline \multirow[t]{2}{*}{ Sulfonylurea } & Chlorsulfuron $^{7 \mathrm{a}}$ & 15 & & & & $\mathrm{X}$ \\
\hline & Sulfometuron $^{7 \mathrm{a}}$ & 15 & $\mathrm{X}$ & & & \\
\hline Glycine & Glyphosate ${ }^{7 c}$ & 540 & $\mathrm{X}$ & & & \\
\hline
\end{tabular}

${ }^{a}$ Nonionic surfactant (alcohol alkoxylate 1,000 $\left.\mathrm{g} \mathrm{L}^{-1}\right){ }^{8}$

${ }^{b}$ Crop oil surfactant (esterified seed oil adjuvant). ${ }^{9}$

${ }^{c}$ Herbicides did not require addition of adjuvant according to manufacturer's label. 


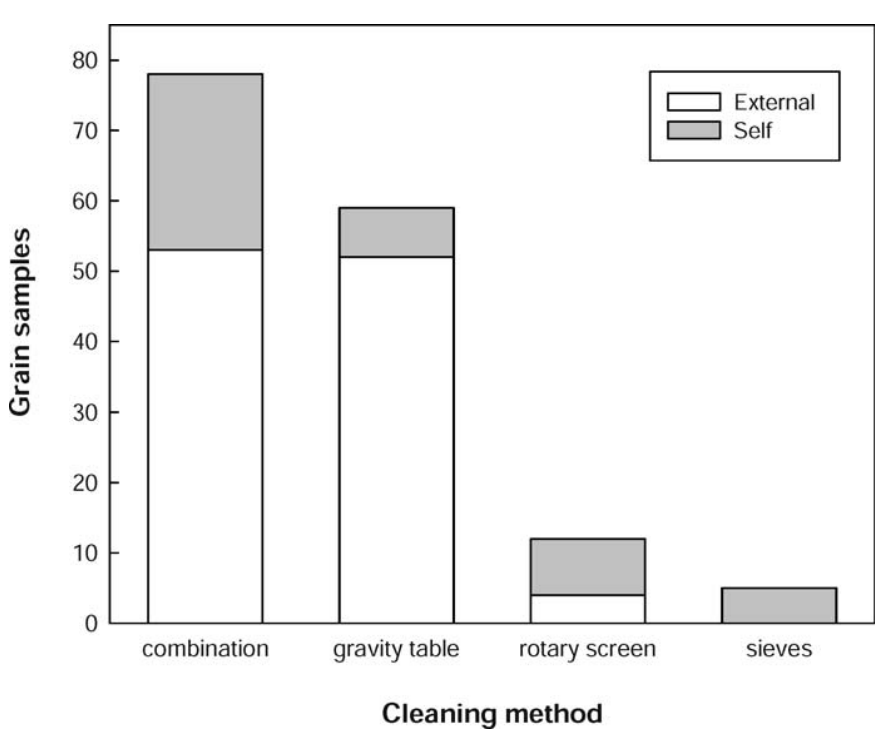

Figure 2. Cleaning methods used to remove weed seeds for each of the 154 crop samples. Four types of methods were employed: gravity table (38\%), rotary screen $(8 \%)$, sieves $(3 \%)$, or a combination of more than one method $(51 \%)$. Methods were also categorized by location of cleaning, with grain either cleaned by the farmer (self, 29\%) or by an external independent cleaning contractor (external, 71\%).

species), only rigid ryegrass and wild radish seeds, which had a minimum average of 14 seeds $10 \mathrm{~kg}^{-1}$ grain, were analyzed separately. A linear mixed model was used to examine the effects of percent of seed cleaned, cleaning method, cleaning location, cleaning operator, region, crop type, grain source, and year (as fixed effects) on the square root of the total average number of seeds. A square root transformation was required to ensure that the statistical assumptions underlying the model were valid. Farmer was included as a random effect in the model. Nonsignificant factors were removed from the model and the effects of the remaining factors were estimated from the model. All statistical analyses were conducted using Genstat. $^{3}$

\section{Results}

Crop Seeds and Cleaning Methods. Of the 154 cleaned crop seed samples collected, 85 were wheat and 69 were an alternative crop (Table 1). Nearly all (94\%) grain was sourced from within the farm with the remainder purchased from outside sources. Four methods were used to clean the crop seed samples (Figure 2), with combination the most common method $(51 \%)$, followed by gravity table $(38 \%)$, then rotary screen $(8 \%)$, and sieves $(3 \%)$. Cleaning of crop seed was largely conducted by independent crop seed cleaning contractors $(71 \%)$ with only $29 \%$ of samples cleaned by the farmer; however, more farmers tended to clean their lupin crops (39\%) than their cereal crops (27\%). Of the 16 uncleaned crop seed samples, nine were wheat and seven were an alternative crop (barley and lupin), with most samples sourced from within the farm (94\%).

Crop Seed Contamination with Weed Seeds. A total of $73 \%$ of all cleaned crop seed samples had some level of weed seed contamination (Table 3), with an average of $62 \pm 11$ weed seeds $10 \mathrm{~kg}^{-1}$ grain. This was slightly lower than farmer perceptions of contamination levels, with $81 \%$ assuming some weed seed contamination within their crop seed (data not shown); however, farmers expected an average number of 28 \pm 3 seeds $10 \mathrm{~kg}^{-1}$ grain, which was substantially less than the 62 weed seeds $10 \mathrm{~kg}^{-1}$ grain found.

Eleven different weed seed species contaminating crop seed were identified (Table 3), comprising nine common agricultural weed species (found within $69 \%$ of samples with an average of $56 \pm 11$ seeds $10 \mathrm{~kg}^{-1}$ grain) and two volunteer crop contaminants (found in $27 \%$ of samples with an average of $6 \pm 2$ seeds $10 \mathrm{~kg}^{-1}$ grain). The most common weed seed contaminants were rigid ryegrass $(45 \%)$, wild radish $(30 \%)$, brome (29\%), and wild oat (24\%). These four weed species also had the highest contamination levels with 28, 14, 9, and 4 seeds $10 \mathrm{~kg}^{-9}$ grain, respectively. The remaining five weed species were found in fewer than $5 \%$ of samples, with an average of $<1$ seed $10 \mathrm{~kg}^{-1}$ grain. Samples that were cleaned by external professional seed cleaning contractors had substantially lower seed contamination with a total of $50 \pm$ 12 seeds $10 \mathrm{~kg}^{-1}$ grain, compared to samples cleaned by the farmer with $91 \pm 24$ seeds $10 \mathrm{~kg}^{-1}$ grain (data not shown).

There were clear differences in the level of weed seed contamination between crops, with cereals having a slightly higher seed contamination (wheat, $61 \pm 15$ seeds $10 \mathrm{~kg}^{-1}$ grain; barley, $53 \pm 21$ seeds $10 \mathrm{~kg}^{-1}$ grain) than lupins ( $43 \pm$ 16 seeds $10 \mathrm{~kg}^{-1}$ grain) (Table 3). Furthermore, a greater number of cereal samples (wheat, $75 \%$; barley, $71 \%$ ) than

Table 3. Contamination levels and average number of foreign seeds $10 \mathrm{~kg}^{-1}$ cleaned crop seed. Blank spaces indicate no seed was found.

\begin{tabular}{|c|c|c|c|c|c|c|c|c|c|}
\hline \multirow[b]{2}{*}{ Common name } & \multirow[b]{2}{*}{ Scientific name } & \multicolumn{2}{|c|}{ All crops } & \multicolumn{2}{|c|}{ Wheat } & \multicolumn{2}{|c|}{ Barley } & \multicolumn{2}{|c|}{ Lupin } \\
\hline & & $\begin{array}{l}\text { \% Samples } \\
\text { contam. }\end{array}$ & $\begin{array}{l}\text { No. seeds } \\
10 \mathrm{~kg}^{-1}\end{array}$ & $\begin{array}{l}\text { \% Samples } \\
\text { contam. }\end{array}$ & $\begin{array}{l}\text { No. seeds } \\
10 \mathrm{~kg}^{-1}\end{array}$ & $\begin{array}{l}\% \text { Samples } \\
\text { contam. }\end{array}$ & $\begin{array}{l}\text { No. seeds } \\
10 \mathrm{~kg}^{-1}\end{array}$ & $\begin{array}{l}\text { \% Samples } \\
\text { contam. }\end{array}$ & $\begin{array}{l}\text { No. seeds } \\
10 \mathrm{~kg}^{-1}\end{array}$ \\
\hline Rigid ryegrass & Lolium rigidum Gaudin & 45 & 28 & 54 & 42 & 44 & 16 & 21 & 3 \\
\hline Brome & Bromus spp. & 29 & 9 & 29 & 7 & 43 & 11 & 7 & 13 \\
\hline Wild oat & Avena fatua $\mathrm{L}$. & 24 & 4 & 25 & 2 & 32 & 12 & 11 & $<1$ \\
\hline Barley grass & Hordeum spp. & 4 & $<1$ & 5 & $<1$ & 2 & $<1$ & 4 & $<1$ \\
\hline Paddymelon & $\begin{array}{l}\text { Cucumis myriocarpus } \\
\text { E. Mey. Ex Naud. }\end{array}$ & 1 & $<1$ & 1 & $<1$ & & & & \\
\hline & Carthamus sp. & 1 & $<1$ & 1 & $<1$ & & & & \\
\hline Total weed species & & 69 & $56 \pm 11$ & 75 & $61 \pm 15$ & 71 & $53 \pm 21$ & 50 & $43 \pm 16$ \\
\hline Volunteer legume & & 16 & 4 & 9 & $<1$ & 37 & 14 & 7 & $<1$ \\
\hline Volunteer cereal & & 16 & 2 & 18 & 2 & 12 & 4 & 14 & $<1$ \\
\hline Total volunteer species & & 27 & $6 \pm 2$ & 24 & $3 \pm 1$ & 39 & $18 \pm 7$ & 21 & $<1$ \\
\hline
\end{tabular}


Table 4. Contamination levels and average number of seeds $10 \mathrm{~kg}^{-1}$ of uncleaned grain for each foreign species. A total of 16 samples were collected.

\begin{tabular}{llcc}
\hline Common name & \multicolumn{1}{c}{ Scientific name } & $\begin{array}{c}\text { Contamination } \\
\text { (\% of samples) }\end{array}$ & $\begin{array}{c}\text { Ave. seed number } \\
10 \mathrm{~kg}^{-1} \text { grain }\end{array}$ \\
\hline Rigid ryegrass & $\begin{array}{l}\text { Lolium rigidum Gaudin } \\
\text { Waphanus } \\
\text { Wild radish }\end{array}$ & 94 & 941 \\
& $\begin{array}{l}\text { raphanistrum } \mathrm{L} . \\
\text { Bromus } \text { spp. }\end{array}$ & 88 & 491 \\
Brome & Avena spp. & 63 & 11 \\
Wild oat & Hordeum spp. & 60 & 82 \\
Barley grass & Malva parviflora $\mathrm{L}$. & 6 & 2 \\
Little mallow & 19 & 4 \\
Three-cornered jack & Emex australis Steinh. & 6 & 2 \\
Fescues & Vulpia spp. & 6 & $<1$ \\
Total weed species & Carthamus spp. & 100 & $1,537( \pm 471)$ \\
Volunteer legume & & 31 & 6 \\
Volunteer cereal & & 31 & 2 \\
Total volunteer species & 56 & $8( \pm 3)$ \\
Total contamination & & 100 & $1,545( \pm 475)$ \\
\hline
\end{tabular}

lupin samples $(50 \%)$ were contaminated with weed seeds $(\mathrm{P}<0.05)$. The most common weed seed contaminant in wheat was rigid ryegrass $(54 \%)$ followed by wild radish (32\%), brome (29\%), and wild oat (25\%). These four species also had the highest contamination levels with $42,10,7$, and 2 seeds $10 \mathrm{~kg}^{-1}$ grain, respectively. Rigid ryegrass was also the most common contaminant in barley $(44 \%, 16$ seeds $\left.10 \mathrm{~kg}^{-1}\right)$, although it was followed closely by brome $(43 \%, 11$ seeds $\left.10 \mathrm{~kg}^{-1}\right)$, then wild oat $\left(32 \%, 12\right.$ seeds $\left.10 \mathrm{~kg}^{-1}\right)$, and wild radish $\left(24 \%, 13\right.$ seeds $\left.10 \mathrm{~kg}^{-1}\right)$. The same four weed species were again the most frequent contaminant of lupin crops (Table 3); however, in this case, wild radish was the most common contaminant (32\%) with the highest infestation $(27$ seeds $10 \mathrm{~kg}^{-1}$ grain), followed by rigid ryegrass $(21 \%, 3$ seeds $\left.10 \mathrm{~kg}^{-1}\right)$, wild oat $\left(11 \%,<1\right.$ seed $\left.10 \mathrm{~kg}^{-1}\right)$, and brome (7\%, 13 seeds $\left.10 \mathrm{~kg}^{-1}\right)$.

All crop seed samples that were not cleaned (Table 4) were contaminated with foreign seeds, with an average of 1,545 \pm 471 seeds $10 \mathrm{~kg}^{-1}$ grain. This level of contamination was almost 25 times higher than for the cleaned crop seeds $(\mathrm{P}<0.01)$. When comparing samples from the same farm, cleaned samples had significantly less contamination than uncleaned samples $(\mathrm{P}<0.01)$. Similar to cleaned samples, rigid ryegrass, wild radish, brome, and wild oat were the most common contaminants with the highest seed numbers.

Herbicide Resistance Status of Contaminant Weed Seed. The majority of rigid ryegrass populations recovered from the contaminated crop samples were resistant to the herbicides sulfometuron (90\%), diclofop (89\%), sethoxydim (90\%), and clethodim (61\%) (Table 5); however, the level of resistance within populations varied significantly (data not shown). All rigid ryegrass seedlings were glyphosate susceptible. Most wild radish populations were resistant to chlorsulfuron (78\%). Several of the wild oat populations were resistant to diclofop (28\%); however, all brome populations were susceptible to fluazifop. The majority of resistant wild radish populations came from the more northern regions, while rigid ryegrass resistance was widely dispersed (data not shown), a result similar to that found in preharvest herbicide resistance surveys in Western Australia (Owen et al. 2007; Walsh et al. 2007).

Effect of Management and Crop Factors on Contamination Levels. The type of cleaning method employed strongly
Table 5. The number of populations tested for each herbicide and the percentage (\%) of populations containing herbicide-resistant weeds

\begin{tabular}{llcc}
\hline Weed species & Herbicide & Populations tested & \% Resistance \\
\hline Rigid ryegrass & Diclofop & 39 & 89 \\
& Clethodim & 18 & 61 \\
& Sethoxydim & 30 & 90 \\
& Sulfometuron & 21 & 90 \\
Wild radish & Glyphosate & 19 & 0 \\
Wild oat & Chlorsulfuron & 19 & 78 \\
Brome & Diclofop & 7 & 28 \\
\hline
\end{tabular}

influenced the contamination level of the crop seed $(\mathrm{P}<0.01)$. For all crop seed samples, using a gravity table produced the lowest weed seed contamination levels followed by rotary screen and combination, which had similar levels, then sieves (Figure 3). When considering rigid ryegrass and wild radish contamination levels only, cleaning method again had a significant effect on the contamination level of samples $(\mathrm{P}<0.05)$. However, no consistent patterns were observed (data not shown).

No other crop or management factors had any significant influence on weed seed contamination levels, except for rigid ryegrass which was affected by crop type $(\mathrm{P}<0.01)$, and wild radish which was affected by cleaning location $(\mathrm{P}<0.05)$. Higher rigid ryegrass contamination was found in wheat $(42$ \pm 12 seeds $10 \mathrm{~kg}^{-1}$ grain) than barley $\left(16 \pm 5\right.$ seeds $\left.10 \mathrm{~kg}^{-1}\right)$ or lupin $\left(3 \pm 1\right.$ seeds $\left.10 \mathrm{~kg}^{-1}\right)$. Cleaning of grain samples by an external cleaning business resulted in lower wild radish contamination $\left(6 \pm 2\right.$ seeds $\left.10 \mathrm{~kg}^{-1}\right)$ than self cleaning by farmers $\left(32 \pm 10\right.$ seeds $\left.10 \mathrm{~kg}^{-1}\right)$.

\section{Discussion}

Our study has confirmed that many farmers are unknowingly introducing substantial levels of weed and volunteer crop seeds into their farming systems at crop seeding, even though crop seed cleaning techniques are employed. Furthermore, our

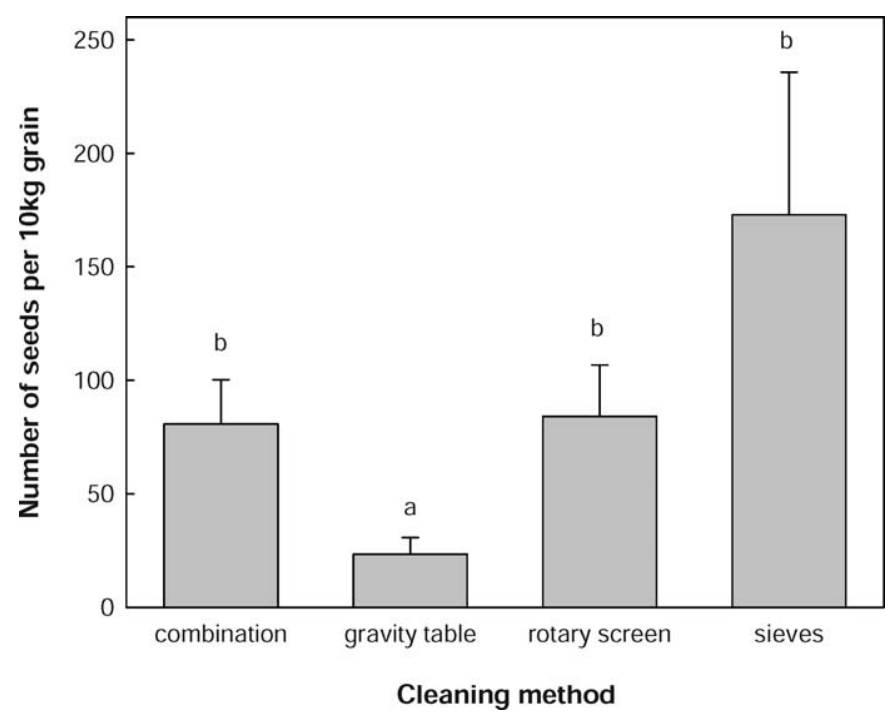

Figure 3. Contamination levels of each cleaning method for all contaminants. Four types of methods were employed: gravity table (38\%), rotary screen $(8 \%)$, sieves $(3 \%)$, or a combination of more than one method $(51 \%)$. Significant differences $(\mathrm{P}<0.05)$ between treatments are indicated by letters, with those sharing common letters being not significantly different from each other. 
results show that many of these contaminating weed seed populations are resistant to a range of commonly used postemergent herbicides, indicating that farmers are seeding herbicide-resistant weed seeds directly into their crop fields. Although the level of weed seed contamination perceived by farmers was comparable to our results, actual seed numbers were substantially higher than perceived by farmers, indicating that they are severely underestimating the amount of weed seed contamination within crop seed. Sowing crop seed contaminated with weed seed, even at low levels, has a potential long-term impact on subsequent decisions such as weed management options. In the field, the level of weed seed contamination (62 weed seeds $10 \mathrm{~kg}^{-1}$ grain) equates to 465 foreign seed contaminates per hectare (based on an average seeding rate of $75 \mathrm{~kg} \mathrm{ha}^{-1}$ ), of which many of these rigid ryegrass seeds are likely to be resistant to commonly used post-emergent herbicides. A study by Llewellyn et al. (2009) found that although the majority of fields in the Western Australian grain belt contained resistant rigid ryegrass populations, these fields actually had low plant numbers with an average density of 1 to 2 plants $\mathrm{m}^{-2}$. This result is similar to our study and shows that farmers are able to maintain weed populations at low densities even when they have herbicide-resistant populations. The long-term nature of the soil seed bank of annual weeds is an important factor leading to low economic maximum weed densities (Cousens 1987). Herbicide-resistant rigid ryegrass populations are usually maintained at the same low densities as susceptible populations (Llewellyn et al. 2009); however, regardless of resistance status, if these weeds were not managed then each plant would produce $>500$ seeds which are then returned back into the farming system. This highlights the importance of hygiene practices such as grain cleaning and using a number of options available to manage weeds in farming systems.

The most common weed species found within crop seed samples were rigid ryegrass, wild radish, brome, and wild oat, belonging to the Poaceae and Asteraceae families. These species are also the most dominant and widespread weed species of Western Australian cropping fields (Owen et al. 2007; Owen and Powles 2009; Walsh et al. 2007). The positive relationship between field abundance and weed seed contamination of crop seed has also been observed by Shimono and Konuma (2008), with field abundance the most significant factor affecting the number of weed seeds contaminating wheat samples imported into Japan. Weed contamination is a reflection of crop management and the regions they are grown in (Scott and Hampton 1985), emphasizing the importance of crop hygiene (such as clean harvest and tillage machinery) and weed control during the cropping phase. As illustrated by our study, a large proportion of the contaminating weed seeds which would be planted with the crop seed are likely to be resistant to commonly used herbicides, and therefore herbicide control options will be extremely restricted. In particular, grass management options in cereals will be limited given the high level of herbicideresistant grass species already present in Western Australia (Owen et al. 2007). Volunteer cereal seeds within a cereal crop are also difficult to manage as there are limited herbicide options available; thus crop rotations and the use of clean crop seed are extremely important weed management tools.

As expected, the crop seed cleaning method employed had a significant impact on the level of weed seed contamination, with use of the gravity table method resulting in the lowest weed seed contamination levels. However, regardless of cleaning method, cleaned seed had significantly less weed seed contamination than uncleaned indicting the importance of employing crop cleaning techniques. Generally seed cleaning by an external crop seed contractor produced much lower levels of weed seed contamination than the farmercleaned crop seed. This could be due to that fact that the majority of external crop seed cleaning contactors used the gravity table, the most effective method; whereas, farmers used a variety of cleaning methods, including sieves, found to be the least effective crop cleaning method. Although it is possible to achieve $100 \%$ clean crop seed, with our study showing that $27 \%$ of farmers had weed-free crop seed, it is unlikely that (using only the current cleaning methods) weed seeds will be completely removed; therefore, other factors such as field abundance and crop hygiene are highly likely to have an influence on weed seed contamination levels.

It has been suggested that timing of weed seed dispersal might be an important factor influencing the number of contaminants within crop seed (Shimono and Konuma 2008). A large proportion of mature rigid ryegrass seeds do not fall from spikes spontaneously (Blanco-Moreno et al. 2004), indicating a high potential to be incorporated into the harvested grain. Like rigid ryegrass, the seeds of volunteer crops may also have been harvested along with the crop seed. In contrast, as wild oat plants generally shed most of their seeds prior to harvest (>90\%) (Barroso et al. 2006), the high level of crop seed contamination with this species may have come from other sources such as silos, transport vehicles, or harvest machinery. We expected that weed seeds whose size differed from that of the grain crop would be easily eliminated; however, we did not find such a relationship as rigid ryegrass, being smaller than most crop seeds, was the most common contaminant of cereals. As also found by Shimono and Konuma (2008), seeds of various sizes have the same potential to be removed in the cleaning process, except for very big seeds (i.e., volunteer legume in wheat samples).

Crop type had a significant effect on the level of rigid ryegrass seeds in cereal crops, with wheat having significantly higher numbers than barley. Since the grain size of barley and wheat is similar, we would have expected similar levels of contamination. However, barley is generally considered more competitive against weeds such as rigid ryegrass than wheat (Lemerle et al. 1995; Paynter and Hills 2009), and therefore the number of rigid ryegrass seeds contaminating barley may have been less due to a lower weed abundance in the field initially. Crop also had an effect on the level of weed seed contamination, with wild radish being the most common weed of pulse crops and rigid ryegrass the most common weed of cereal crops. This is likely due to the fact that many rigid ryegrass populations are resistant to in-crop selective herbicides, therefore it is difficult to remove these seedlings during the cropping phase and thus large numbers of rigid ryegrass seed are then harvested with the crop.

The large majority of farmers grew and conserved their own crop seed rather than purchasing certified seed from an external source. Although the purchase of certified seed is a guarantee of varietal purity and seed quality, it does not guarantee weed seed-free status. For example, Western Australian certified wheat can contain up to 15 foreign seeds (excluding wild radish) and a maximum of one volunteer crop seed per kilogram of grain (Davies and Holland 2008). This is substantially higher than that observed within this study with 
an average of 6 seeds $\mathrm{kg}^{-1}$, although wild radish was the second most common seed contaminant. Therefore, planting certified seed may still introduce weed seeds into the farming system, further supporting the importance of cleaning crop grain using the most effective techniques prior to seeding.

International trade can also be a way for alien species invasions into new habitats. Many weed seeds have been shown to be introduced by grain trade (Shimono and Konuma 2008) and can have significant impacts on the new ecosystems (Mack et al. 2000). This could cause major economic losses for agricultural industries as well as affecting potential markets for grain traded to other countries. If grain traded between Australia and other countries was found to contain herbicide-resistant weed seeds, this could have potentially devastating effects for Australian export markets, increasing the necessity for using clean crop seed. Weed seed contamination could also reduce the quality of the crop's end use; for example, weed seed contamination in rapeseed (Brassica napus L.) affected the quality of the resulting oil and meal (Davis et al. 1999).

Llewellyn et al. (2002) found that a high proportion of growers perceived that herbicide resistance could be imported into a field though means such as seed movement and pollen flow. A later survey found that $52 \%$ of farmers perceived that weed seeds would be brought back into the field with grain for sowing, $42 \%$ thought it would be reintroduced with hay or grain for feed, and $54 \%$ thought seeds/plants would be carried by livestock, vehicles, or machinery (Llewellyn and Allen 2006). Therefore, farmers appear to be well aware of how weed seeds can be brought into farming systems, which emphasizes the importance of on-farm management. Systems that aim to promote farm hygiene (e.g., Hanson 2004) such as meticulous seed cleaning, reducing weed field burdens, crop rotations, and sanitizing tillage and harvesting equipment between fields will help to prevent the spread of new weed species, noxious weeds, and herbicide resistance.

Sowing crop seed contaminated with resistant weed seeds, even at perceived low levels, has a potential long-term impact on subsequent management options. Although crop seedcleaning techniques are improving, it will remain impossible to completely remove all foreign weeds seeds from grain due to high costs (Shimono and Konuma 2008). Thus it is essential to use a combination of farm hygiene methods to ensure clean crop seeds are sown into agricultural systems.

\section{Sources of Materials}

${ }^{1}$ Seed clipper, Endecotts Ltd., 9 Lombard Road, London, SW19 3TZ, England.

2 TeeJet ${ }^{\circledR}$ XR1 1001 flat fan, TeeJet Australasia Pty Ltd, 65 West Fyans Street, Newtown, Victoria 3220, Australia.

${ }^{3}$ GenStat, version 11.1, VSN International Ltd., Waterhouse Street, Hemel Hempstead, HP11ES, UK.

${ }^{4}$ Diclofop, sethoxydim, Bayer CropScience, Pty. Ltd., 391-393 Tooronga Road, East Hawthorn, VIC, Australia.

${ }^{5}$ Fluazifop, Syngenta Crop Protection Pty. Ltd., Level 1, 2-4 Lyonpark Road, Macquarie Park, NSW, Australia.

${ }^{6}$ Clethodim, Sumitomo Chemical Australia, 501 Victoria Avenue, Chatswood, NSW, Australia.

${ }^{7}$ Chlorsulfuron, sulfometuron, glyphosate, Nufarm Australia, Ltd., 4 Laverton Rd., North Victoria, Australia.
${ }^{8}$ Nonionic surfactant, Crop Care Australasia Pty. Ltd., Portal North, Unit 15, 16 Metroplex Avenue, Murarrie, QLD, Australia.

${ }^{9}$ Crop oil concentrate, Victorian Chemicals, 83 Maffra Street, Coolaroo, VIC, Australia.

\section{Acknowledgments}

The authors are grateful for the assistance from the 74 Western Australian farmers and acknowledge statistical advice from Jane Speijers and technical assistance by Western Australian Herbicide Resistance Initiative staff. This study was mostly funded by the Grains and Research Development Corporation (GRDC).

\section{Literature Cited}

Barroso, J., L. Navarrete, M. J. Sanchez Del Arco, C. Fernandez-Quintanilla, P.J.W. Lutman, N. H. Perry, and R. I. Hull. 2006. Dispersal of Avena fatua and Avena sterilis patches by natural dissemination, soil tillage and combine harvesters. Weed Res. 46:118-128.

Benvenuti, S. 2007. Weed seed movement and dispersal strategies in the agricultural environment. Weed Biol. Manag. 7:141-157.

Blanco-Moreno, J. M., L. Chamorro, R. M. Masalles, J. Recasen, and F. X. Sanx. 2004. Spatial distribution of Lolium rigidum seedlings following seed dispersal by combine harvesters. Weed Res. 44:375-387.

Cousens, R. 1987. Theory and reality of weed control thresholds. Plant Prot. Q. 2:13-20.

Davies, M. and M. Holland. 2008. AGWEST Plant Laboratories Seed Certification Rules 2008. Perth, Australia: Department of Agriculture and Food, Western Australia. 52 p.

Davis, J. B., J. Brown, J. Brennan, and D. C. Thill. 1999. Predicting decreases in canola (Brassica napus and B. rapa) oil and meal quality caused by contamination by Brassicaceae weed seeds. Weed Technol. 13:239-243.

Dewey, S. A., D. C. Thill, and P. W. Foote. 1985. Weed seed contamination of cereal grain seedlots—a drillbox survey. Current Information Series No. 767. Moscow, ID: University of Idaho. 2 p.

Dewey, S. A. and R. E. Whitesides. 1990. Weed seed analysis from four decades of Utah small grain drillbox surveys. Proc. Western Soc. Weed Sci. 43:69.

Hanson, C. 2004. Agricultural contractors bail up weeds-an accreditation system to reduce weed spread in Tasmania. Page 601 in Proceedings of the 14th Australian Weeds Conference. Sydney, Australia: Weed Society of New South Wales.

Harper, J. L. 1977. Population Biology of Plants. London: Academic Press. Pp. 33-60.

Lemerle, D., B. Verbeek, and N. Coombes. 1995. Losses in grain yield of winter crops from Lolium rigidum competition depends on crop species, cultivar and season. Weed Res. 35:495-502.

Llewellyn, R. S. and D. M. Allen. 2006. Expected mobility of herbicide resistance via weed seeds and pollen in a Western Australian cropping region. Crop Prot. 25:520-526.

Llewellyn, R. S., F. H. D’Emden, M. J. Owen, and S. B. Powles. 2009. Herbicide resistance in rigid ryegrass (Lolium rigidum) has not led to higher weed densities in Western Australian cropping fields. Weed Sci. 57:61-65.

Llewellyn, R. S., R. K. Lindner, D. J. Pannell, and S. B. Powles. 2002. Resistance and the herbicide resource: perceptions of Western Australian grain growers. Crop Prot. 21:1069-1075.

Mack, R. N., D. Simberloff, W. M. Lonsdale, H. Evans, M. Clout, and F. A. Bazzaz. 2000. Biotic invasions: causes, epidemiology, global consequences, and control. Ecol. Appl. 10:689-710.

McCanny, S. J. and P. B. Cavers. 1988. Spread of proso millet (Panicum miliaceum L.) in Ontario, Canada. II. Dispersal by combines. Weed Res. 28:67-72.

Moerkerk, M. R. 2002. Seed box survey of field crops in Victoria during 1996 and 1997. Pages 55-58 in Proceedings of the 13th Australian Weeds Conference. Perth, Australia: Plant Protection Society of Western Australia.

Niknam, S. R., M. R. Moerkerk, and R. D. Cousens. 2002. Surveys of weeds in Victorian farming systems. Pages 59-62 in Proceedings of the 13th Australian Weeds Conference. Perth, Australia: Plant Protection Society of Western Australia.

Owen, M., M. J. Walsh, R. S. Llewellyn, and S. B. Powles. 2007. Widespread occurrence of multiple herbicide resistance in Western Australian annual ryegrass (Lolium rigidum) populations. Aust. J. Agric. Res. 58:711-718.

Owen, M. J. and S. B. Powles. 2009. Distribution and frequency of herbicideresistant wild oat (Avena spp.) across the Western Australian grain belt. Crop Past. Sci. 60:25-31. 
Paynter, B. H. and A. L. Hills. 2009. Barley and rigid ryegrass (Lolium rigidum) competition is influenced by crop cultivar and density. Weed Technol. 23:40-48.

Pleasant, J. M. and K. J. Schlather. 1994. Incidence of weed seed in cow (Bos sp.) manure and its importance as a weed source for cropland. Weed Technol. 8:304-310

Powles, S. B. and G. Cawthray. 1999. Weed seed infestation of crop seed. Pages 70-73 in Proceedings of the Agribusiness Crop Updates. Perth, Australia: Department of Agriculture Western Australia.

Scott, D. and J. Hampton. 1985. Aspects of seed quality. Pages 43-52 in M. Hare and J. Brock, eds. Producing herbage seeds, Grasslands Research and Practice Series No. 2. Palmerston North: New Zealand Grassland Association.
Shimizu, N. 1998. Recent situation of invasion and diffusion of alien weeds and its control. Jpn. J. Ecol. 48:79-85.

Shimono, Y. and A. Konuma. 2008. Effects of human-mediated processes on weed species composition in internationally traded grain commodities. Weed Res. 48:10-18.

Thill, D. C. and C. A. Mallory-Smith. 1997. The nature and consequence of weed spread in cropping systems. Weed Sci. 45:337-342.

Walsh, M. J., M. J. Owen, and S. B. Powles. 2007. Frequency and distribution of herbicide resistance in Raphanus raphanistrum populations randomly collected across the Western Australian wheatbelt. Weed Res. 47:542-550.

Received December 8, 2009, and approved May 17, 2010. 